\title{
$[3]$
}

\section{A Redistributive Model for Analyzing Government Mediation and Law in Family, Community, and Industry in a New England Industrial City}

June Nash

The ideology of a free market attributes the economic decline of American industry to government intervention. Yet most of the restrictions on business enterprise have evolved within corporate capitalist structures, both with the help of government acting in their behalf and independently within oligopolistic structures. Government interventions promoted by corporations are so entangled with those designed to rectify the imbalance endemic in capitalist society that any attack on government regulation is necessarily very selective. Redistributive mechanisms operate in all the major institutions concerned with production, exchange, and consumption. These may be customary or backed by law; some may be considered "natural," and hence justifiable in a freeenterprise economy, while others are tagged as special-interest provisions.

An analysis of the redistribution that occurs in several arenas-at the site of production in the firm, at the site of reproduction in the household, and at the level of the state in public agencies-will clarify the political aspects of what are often treated as simple economic transactions. The study of exchange relations by Polanyi, Arensberg, and Pearson (1957:253ff.) points to redistributive mechanisms as occurring in the evolution from simple exchange to market practices, with redistribution a means of legitimizing and strengthening the political position of the 
patriarchal households of Hebrew, Greek, and Roman times. Their linkage of redistribution with the legitimization of authority is an ongoing process that persists in the modern welfare state, where it coexists uneasily with market mechanisms of exchange as government agencies at national, state, and local levels try to overcome the inequities incumbent on capital accumulation. So important are these counterweights to centralization of economic power and polarization of wealth that the current attack on regulations that have evolved in trade union and political struggles might threaten the corporate hegemony central to the modern state.

A redistributive model of the evolution of custom and law must consider the coordinates of time, place, and role relationships operating in each institutional context. Redistribution involves people in a chain of interactions relating to corporate group structures that persist beyond the life of any individual and may be independent of the dyadic ties existing between any members. The time horizon often involves several generations in the case of families, and spans a century in the case of corporations (Gluckman 1968). Yet government agencies that intervene in these structures operate on annual budgets within the four-year presidential terms, where priorities are set in response to a changing political ideology. The difficulty in coordinating these differently timed institutions can defeat long-term goals, usually in a way that is not favorable to the weaker member.

Differential degrees of commitment to space also create problems of coordination for a work force, a community, and a corporation. Automated technology and integrated production have increased the mobility of firms, enabling them to set up production sites in remote places and dismantle them with less cost and disruption of corporation schedules than formerly. Tax laws favoring investment in new sites and in new technology exacerbate this tendency toward mobility. Workers tied by family, mortgages, and cultural preferences to specific areas and communities are the victims of the new mobility. The threat by corporations to move is a powerful means of reducing claims for returns to workers in the form of wages and to communities in the form of taxes, thus upsetting the redistributive mechanisms won over decades.

The disparity in time and space commitments of corporations, communities, and families makes coordination of social planning ever more difficult. Added to this are differentiated goals of segments of the population. The allocation of roles in production is locked into a segmented market, with stereotypes related to gender, age, and ethnicity channel- 
ing people into differentially compensated jobs that vary in a status hierarchy. While the mystique of job specialization sets criteria guiding the allocation of these roles, empirical studies indicate that education and skill are not attuned to rewards. ${ }^{1}$ The labor market is shaped by class, ethnic, and gender dominance hierarchies in the wider society. These segmented markets control entry through corporate group structures in trade unions and professional societies with disparate and often conflicting goals. ${ }^{2}$

The evolution of custom and law regarding distributive mechanisms often fails to address the disparities in time, place, and role commitments. Indeed, the regulations often exacerbate the differences. For example, laws enacted in the nineteenth century restricting exploitation of women and children through limiting the hours of work effectively curbed the competitive position of women in the labor market. Pollution restrictions and Occupational Safety and Health Administration (OSHA) controls ensuring safety in the workplace accelerated capital flight and added to the loss of employment opportunities. Benefits negotiated by trade unions promoted the hiring of temporary and part-time workers. The piecemeal fashion with which social legislation is approached ignores the context in which a solution for one problem becomes the source of even greater problems. In the dismantling of the welfare reforms during the Reagan administration, there has been an even greater tendency to remove programs that effectively reduced disparities in income. The Omnibus Reconciliation Act of 1981 eliminated benefits that enabled many women to work, and the resulting impact was to increase the welfare roles (U.S. Dept. of Housing and Urban Development 1984).

The different and often contradictory impacts of these regulations can be seen more clearly when we observe the process in the interactions within a community. Pittsfield is an industrial city in western Massachusetts that has experienced the rise and decline of textile and electrical machinery manufacturing. ${ }^{3}$ The city has undergone all the major

${ }^{1}$ See, e.g., Bibb and Form 1977; U.S. Department of Labor 1982a, 1982b. The need for family-organized statistics is becoming more recognized. Sylvia Lazos Terry (U.S. Department of Labor 1982b:39) points out: "Unemployment affects the economic well-being of the family unit as well as that of the individual." However, the impact of the family is often cushioned by the presence of other earners or other sources of income.

${ }^{2}$ Gordon, Reich, and Edwards (1982) discuss the political consequences of a gender and racially segmented work force, but they disregard the impact of redistribution of returns from those segregated jobs in the domestic arena (see Nash 1983).

${ }^{3}$ See Boltwood 1916, Smith 1876, and Willison 1957 for local histories of Pittsfield. 
changes affecting corporate capitalism since the turn of the century, when General Electric Company bought the William Stanley Company, which produced the first alternating-current power transformer. General Electric became the principal employer in a city that grew with the expansion of electrical machinery production during World War I and the 1920s. It experienced the rise of industrial trade unions in the late 1930s, participated in the post-World War II strikes, and suffered the loss of many production jobs that went to the plants opened up by General Electric in the South during the 1950s. Smaller competitive capitalist firms have been swallowed up by conglomerates, and many more production jobs employing female workers were lost as they transferred such operations to other sites. In the recession of the 1970s, many more layoffs occurred in the power-transformer division, and only half those workers found jobs in the expanding defense activities with contracts for the Polaris missile and the automatic gearshift for the Bradley $\mathrm{V}$ fighting tank. A major shift in population came about as over 8,000 people, more than one-tenth the population, left town between 1970 and 1985.

This high outward migration, the growing incidence of alcoholism, and divorce and unemployment rates hovering around 8 percent in the United States are measurable signs of the personal and social costs involved in these crises. The holistic view offered here may enable us to evaluate the relative effectiveness of measures that affect the redistribution of the "social fund," defined here as the proceeds from economic activity made socially available through wages and taxes. We shall first look at the special arenas in which this occurs: the workplace, or site of production; the household and family, or site of social and biological reproduction; and the public and private agencies that intervene to strike a balance. This artificial separation for analytical purposes will be followed by an integrative view of the interactions occurring daily among all those who participate in them.

\section{Redistribution at the Site of Production}

The fiction contained in marginal productivity theory that wages are direct payments for each individual worker's contribution to production conceals the political process of redistribution. ${ }^{4}$ Manager-owners pool

\footnotetext{
4The concept of productivity-bargaining was introduced during World War II in discussions with the War Labor Board. Edelman and Fleming 1965 and Goldberg et al. 1975 include articles in their anthologies that discuss the impact of the rhetoric of productivity
} 
returns from production and disburse them to a wide variety of personnel; only a small portion goes to direct producers. Trade unions and state agencies intervene in those decisions to set the amounts of wages and benefits and their allocation to different segments of the labor force. The accepted purpose of trade unions, in John Kenneth Galbraith's phrasing of mainstream economic theory, is "to replace the determination of wages by the market with a process of negotiation which protects the individual union member from the market" (Galbraith and McCracken 1983:31). The state, in turn, serves "to temper market with price supports, minimum wage legislation, unemployment compensation, and old age pensions" (ibid.).

The issue I raise is whether market forces ever did operate freely to set prices prior to the introduction of trade union and government regulation. Was there ever a time when the supply of and demand for labor determined the actual amount given as wages? How did the different scales of payments for men and women that always existed in large industrial establishments become fixed? Are market forces anything more than ad hoc explanations for what takes place in a political struggle over redistribution?

David Ricardo's thesis that the relative quantity of labor establishes the value of a commodity in exchange casts the issue of what determines the price of labor in the realm of nature. Thus the "natural price of labour," Ricardo (1930:75) states, depends on "the price of the food, necessaries, and conveniences required for the support of the labourer and his family." That which is considered essential is derived from "habit which that money [received as wages] will purchase." But whereas Ricardo posited the exchange value as equivalent to the costs of reproducing labor inhering in the wage, Karl Marx distinguished the surplus value created over and above the wage as the basis for the extraction of profit. How this surplus value is created, expropriated, and distributed is a political relationship between labor and capital (Marx 1973:662-664). Competition among enterprises, just as that among workers, may set a price that fluctuates in the short run with the supply and demand for the product or the labor power, but this does not explain the "laws" governing the relationship. Marx states, "Competition generally, this essential locomotive force of the bourgeois economy, does not

on bargaining. Union negotiations based on a "needs approach" are less effective than productivity-bargaining during an inflationary economy, when wages have already been set above survival needs, but the difficulty with productivity-bargaining is that the political stance of collective solidarity is broken and discrepancies arise. 
establish its laws, but is rather their executor. Unlimited competition is therefore not the presupposition for the truth of the economic laws, but rather the consequence-the form of appearance in which their necessity realizes itself' (ibid., p. 552).

Both capitalists and workers have worked unceasingly to protect their interests from the untrammeled operation of the market. Both sides have appealed to government and other institutions, including religious, kinship-based, and community networks. Both trade unions and corporate managers have tried to manipulate the supply of labor-the former by limiting access to jobs, the latter by encouraging immigration at an earlier time in history, restricting entry of large employers in communities that have established plants or, currently, moving production abroad. These actions are largely confined to the monopoly sector of capitalist enterprise, where larger profit margins and longer time horizons enable unions to extend the range of their control, and corporations to influence state and local governments.

The fact that competitive marginal capitalist firms persist and employ a less favored "secondary" work force changes the nature of this struggle. Alliances are made between representatives of management and workers to protect the vested interests of each. Thus redistribution in the form of wages, salaries, and profits differs according to the type of enterprise as well as the category of work. The strength of the claims made by each segment of the work force is related to the cultural and social characteristics of the members within it, as much as it is to the specific contribution in production. Symbiotic ties relate workers and managers in competitive capitalist firms with those in the monopoly sector in ways that affect their engagement in the political struggle for redistributive gains.

In Pittsfield, the evolution of redistributive mechanisms that went into wage and profit determinations was shaped by features that are distinctive to the electrical machinery industry as well as those characterizing the labor movement. Growth in the electrical machinery industry depended on a large and growing market. The U.S. economy met these qualifications in the late nineteenth century. The relative homogeneity of the market for public utilities for the transmission of electrical current, trolley transportation, and industrial dynamos and generators enabled the engineer-entrepreneurs who promoted the industry to plan the production facilities that could produce such gigantic units (Passer 1953:1-4; Walton and Cleveland 1964:16). This all required an unsurpassed level of capital expenditure, which in itself limited the number of competitors. 
Production for such a market required a more dynamic view of supplyand-demand functions than classical or even neoclassical economic analysis permitted. An increase in the supply of electrical current expanded the potential use of electrical products. This consumption in turn stimulated the generation of power, expanding the market for turbine generators and transmission equipment. Ralph Cordiner, president of General Electric in the 1950s, summed up the market outlook that motivated production: "Each new use of electricity accelerates the turn of the circle-creating a bigger potential market for GE products, not only in end-use equipment, but in equipment to produce, transmit, and distribute electric power" (cited in Greenwood 1974:15).

These characteristics of the market for major electrical machinery tied to the consumption of consumer durable goods dependent on the expansion of electricity promoted two strategies in the industry: The first was oligopolistic control of the market shared by the two giants, General Electric and Westinghouse, necessitated by the advanced time horizon and huge capital expenditures required in the production of major electrical machinery. The second was the development of consumer markets through worker insurance, unemployment insurance, and credit unions to ensure installment purchases of durable electrical equipment (Greenwood 1974:15; Passer 1953:4). The first strategy was achieved by 1905, when the first electrical trade association was organized "in the interest of stabilizing market shares and furthering the interests of manufacturers" (Walton and Cleveland 1964:204). The second strategy was targeted in the 1920s, when under Gerard Swope's leadership General Electric set out to promote the consumer utilities market by advancing workers' insurance, pensions, and credit that enabled workers to buy the products they made. Today the credit association and employees' pension fund is an important source for the accumulation of capital that is used for investment, often in overseas branches that compete with national development.

"Welfare capitalism" (Montgomery 1979) operated within a context of repression of independent trade unions with communication channeled through company-controlled councils until $1939.5^{5}$ As a result, wages remained at the same level or lower than during World War I, despite

5Despite the paternalism of workers' councils within the corporation prior to the development of industrial trade-unionism, wage increases were minimal. When the councils voted for a ten-cent increase during the formation of the United Electric (UE) shop, management suppressed the results of the vote. According to Matles, this belied the company's claims that unions were not needed, and the UE gained favor in its drive for membership (Matles and Higgins 1974:67ff.). 
the high market demand throughout the 1920s. Although the workers' councils in each plant put forth wage demands, the company did not heed them (Matles and Higgins 1974). The benefits in pensions and sick leave were minimal, and most were whittled away during the depression. There never were any maternity benefits prior to the organization of the industrial union, and a woman usually lost her job merely for getting married. While the rising demand for labor during the 1920s had little effect on improving wages or hours, the depression had a profound effect on the position of labor. The job became a gift, and supervisors or foremen in hiring positions were courted by desperate job hunters.

The notion of a job being a gift to the worker developed throughout the depression, as management took back some of the gains in security and pensions made in the preceding decade. Thus managerial control extended from determination of the wage share of earnings from sales to the control over redistribution of jobs. A company policy of retaining family heads discriminated against older workers who had grown children and were nearing retirement age. It also discriminated against women, who were never categorized as heads of families even when they were supporting their husbands and children. All married women were fired, whether their husbands were working or not. The Mafia was the only affirmative-action business in town; its agents made sure that the children of widows were given the first chance to distribute bootleg liquor. Since wages had never been allowed to rise very high in response to the increasing demand for labor in the 1920s, there was not a great proportional decrease during the depression. But because there were many layoffs and few worked a full week, all a working family's labor resources were needed to maintain income at subsistence levels. Those who were employed by General Electric were assessed one percent of their earnings to pay people on layoff.

For these reasons, I question Galbraith's claims that trade unions owe their existence to their function of replacing "the determination of wages by the market with a process of negotiation which protects the individual union member from the market" (emphasis added). In fact, trade unions raised wages beyond the subsistence level so that workers could hold out for a market price. Industrial unions altered the basis for negotiating workers' demands at the production site, moving the basis of their claim from subsistence needs to their contribution to production.

Legalization of trade unions with the Wagner Act of 1933, and the establishment of the National Labor Relations Board to enforce the act in 
1935, restructured the field of labor-management relations, not by undermining the market but by legalizing unions and thus strengthening the position of labor within the market. The Fair Labor Standards Act of 1938 confirmed this position by establishing a floor below which the wage payments could not fall with the minimum-wage policy. The rhetoric and strategy of collective-bargaining negotiations are premised on competitive market conditions. This contributed to the bureaucratization of trade unions as they became committed to preserving the legal basis for collective bargaining.

At the same time that these broad hegemonic controls were exerted on the trade unions, such corporations as General Electric limited entry of other large employers into the city. Labor union leaders of the 1950s told me about how General Electric officials discouraged the sale of public property to Sikorsky Aircraft, which wanted to construct a testing base for helicopters being made for the Korean War. Union Carbide was given the cold shoulder when it showed interest in moving corporate headquarters to Pittsfield, and others say that the move by General Motors to open a parts manufacturing plant was discouraged too. Whether these moves were actually opposed by the corporation and the town officials, I do not know, but clearly the terms were not attractive enough to bring them in. That policy changed after the 1969 General Electric strike, when GE workers throughout the nation stayed out for 101 days. ${ }^{6}$ The economic devastation to the local and regional economies effected by this strike was so great that the mayors and national congressmen banded together and tried to get the corporation to accept a federal mediator, a step the union supported.

Following the strike, the corporation changed its policies. Instead of restricting entry into the labor market area by other firms, the managers, many of whom occupied positions on the city's policy-making boards, urged the promotion of new enterprises in the community. It was time to stop being "the big guy on the block"7 and to take a back seat. Expansion of the firm's middle-size and small power transformer production was transferred to Shreveport, Louisiana, and Rome, Georgia, plants.

Capital flight, not only to other sites in the United States but also overseas, became a threat and a reality in subsequent labor problems.

6I have analyzed the changing structure of labor-management relations in a series of strikes occurring between 1916 and 1969 at Pittsfield's General Electric (see Nash 1984).

${ }^{7}$ Quotation from interview with a former head of community relations at Pittsfield General Electric. 
These policies were promoted by tax laws that favored investment in new facilities in the 1970s and 1980s.

Despite the growing freedom from market, community, or even stockholder constraints, corporations have sought further deregulation through their representatives in President Reagan's term of office (see Heldman, Bennett, and Johnson 1981; Freeman 1981). A frontal attack on the minimum wage, the hours ceiling, and OSHA regulations are part of a programmed attempt to reduce labor's position from that of a freely bargaining unit in the market to a repressed, barely surviving member of an internally competitive work force. The politics of redistribution with a growing favorable balance of power and financial resources in the hands of the corporation has in fact destroyed the market processes in the name of which they operate in the monopoly sector.

Deregulation resonates favorably with primary work-force members because of the identification with property-holding, taxpaying interest groups concerned with government spending on welfare. Labor leaders are careful to separate the victories of labor-the National Labor Relations Act, Social Security, Medicare, the Fair Labor Standards Act, and OSHA - from Aid to Families with Dependent Children (AFDC), food stamps, and Medicaid. Having accepted the boundaries to their constituency imposed by the anticommunist cold war tactics of the McCarthy era, the trade union movement has failed to address the broader issues that involve all workers.

The trade union commitment to a market ideology viewing the wage as an isolated economic factor negates the political issues involved in redistribution. While unions accept takebacks in contract negotiations on the basis of competition from abroad and declining productivity, there is as yet no demand for redistribution of profits when gains are made. Even more damaging to their morale is the fact that, when the corporation urged them to improve productivity to save jobs in the power transformer division and they responded by cutting work time and improving quality, they just received further layoffs. When the corporation finally announced in November 1986 that it intended to shut down production of power transformers in the plant and open a facility with the competitor, Westinghouse, in Canada, the workers were outraged. Yet their indignation was not directed at the power of the corporation to direct investment decisions so much as at its failure to adhere to principles of market competition. A delegate to the International Union of Electrical Radio and Machine Workers (IUE) congress at which this decision was announced expostulated, "They are climbing into bed with the competitor and leaving us bare-assed out in the cold!" 
Redistribution at the site of production concerns not only the relative shares of employees and corporate owners and managers. It also bears on the relative shares received by the various parts of a segmented labor market. In a large corporation organized by an industrial union that includes the bulk of the production work force, female workers benefit from contract gains along with men, but their proportionate earnings are lower because of a segregated labor policy. Few women rise above the rank order of 14 in a job hierarchy that ranges from 8 to 24 , while most men enter at that level as stock boys, and after a few years of service most men are distributed in the range of 18 to 20 . Men's jobs were considered more skilled, or heavy, dirty, and requiring a great deal of climbing, lifting, and other active work, while women's jobs were generally sedentary assembly or clerical work. The Equal Opportunity Act of 1972 caused some shake-up of the work force as women in relatively small numbers sought the better-paying though more strenuous male jobs. Equal opportunity requirements are more effective in the large corporation because military contracts are contingent on their fulfillment. The corporation avoids the union contract by hiring temporary "Kelly girls" for much of the clerical work.

Firms in the competitive sector use other strategies for avoiding high wages for females required by union contracts or government regulations. The managers of a small braid factory gave preference to women who were married to General Electric workers because they would not strive for independent retirement benefits for health or retirement through unionization. A plastics company that was bought out by Ethyl Corporation ignored the complementarity inherent in this employment policy, and when it cut off the medical benefits for female workers, the women turned to union organization. When they won a contract, the company cut out the production unit that employed the women on injection mold machines, keeping the skilled, mostly male mold-makers unit.

The complementarity of male/primary, female/secondary employee relationship was beginning to break down as increasing numbers of female-headed families meant that women working in the smaller firms recognized that they could not make their wages cover the costs of raising a family. As a result, female workers were becoming more demanding, and the longest strike in Pittsfield's history was carried out by female workers in a garment factory. When they won a National Labor Relations Board settlement approving a contract with the International Ladies Garment Workers Union, the company went underground and assumed another name until it was finally forced out of business. The 
nurses in the Berkshire Medical Center also proved to be the most militant strikers during our research, and their demands for wage increases and improved shifts won the support of large sectors of the public.

\section{Redistribution in the Family}

The pooling and redistribution of income in the family overcome some of the burdens that the secondary labor force members experience in a segmented job market. Women, who are the largest proportion of lowpaid service workers in the community precisely because of their greater share of domestic responsibility, may exercise some power over the allocation of income of other family members. When married women take on part-time work, their pay covers "extras"-meals in restaurants, entertainment, new furniture purchases. When the job is a full-time commitment, they allocate it to education for the children, clothing for themselves and the children, and a major share in the purchase of food. Children who work full-time and remain at home are expected to pay for their board, but few families charge rent.

This is the "American system." In the early decades of the twentieth century, when immigrants settled in Pittsfield, children turned over their entire paycheck to the family and were given an allowance of fifty cents or a dollar. Parents were expected to save some for their children's marriages and assistance in forming an independent household. Now none of the older generation is alive, and the American system prevails.

Women's commitment to work varies with the number and ages of their children as well as the stability of the husband's job and the kind of work they themselves perform. In our interviews with one hundred General Electric workers, both employed and those on layoff, we found that more than half had spouses who were fully employed. Of those who were married and for whom information on spouses' work was acquired, forty-three (63 percent) worked, and for all but three of them it was a full-time job. Three women went into full-time work when their husbands were laid off. Nine worked at General Electric along with their spouses. Sixteen were engaged in service jobs-for example, hairdressers, nurses, salespeople, waitresses-service work that comprised 43 percent of the employment. Five (13 percent) were schoolteachers. Of the five female workers in the survey only two were married, and both their husbands worked for General Electric. 
Hartman (1981) summarized studies on housework responsibilities when both spouses work performed in the 1960s and 1970s. She concluded that only minimal and insignificant changes had come and that the major difference was that fewer hours were spent doing housework because of more efficient organization of time and better technology. I found considerable differences among generations who began work in the 1930s, 1960s, and 1980s, with continually more progressive attitudes as well as activities related to sharing responsibilities on the part of both spouses. There was a great deal of flexibility in the household division of labor among couples where both worked. All the working women continued to do the shopping, a preference on their part. The outside/inside work division that characterized families with non-wage-working wives persisted with some modifications. The major contrasts are between members of pre-World War II generations and those beginning work after the war. Vicky, whose working career began in 1921 when she was sixteen years old, continued to do all the housework even though she was the main support for her family, which included one child. She describes her routine when she was forced by a layoff at the General Electric plant to seek employment in New York State, where she stayed during the week, returning on weekends: "I liked my job there very much, but I had the upkeep on the house. My husband was here and all the expenses were the same or even more. I used to work six days and come home for three days, then go back to work six more days, then have three more days off. I came home on my three days and cooked up a storm so he'd have food here. That was in 1953." Although she never expressed resentment about this uneven division of labor in the several interviews I had with her, she laughed somewhat scornfully when I asked if her husband minded her working, and when we were raking leaves that fall she swore she would cut down a tree her husband had planted.

Theresa began work as a clerk in General Electric's traffic control office in 1937 when she was seventeen years old. Because of the union she did not lose her job, as Vicky did, when she got married in 1952, and because her husband, who was an alcoholic, never kept a steady job, she was forced to keep on working after having three children. She had the full responsibility for house care and getting the children to day care and schools. Added to this was the burden of caring for the man himself and worrying about his whereabouts when he was not home. She turned to her own family for help, and was proud that she never had to go on welfare. 
Men and women of the younger generation who entered the work force in the 1960s and later have a much more flexible division of labor. When women work outside the house, they arrange their shifts so that one parent will be at home when the children return from school. Tight schedules involve complex routines in the delivering of working spouses and children when there is one car and two jobs. A change in shift for one spouse involves readjustments for the other. Women like working in hospitals, which have full twenty-four-hour work schedules that offer a range of part-time and full-time shifts that they can work in with their husbands' shift. Another preferred employer is the Berkshire Life Insurance Company, which offers excellent day care for employees' children. Fast-food restaurants offer flexible schedules for part-time employees as an alternative to raising wages to attract workers. These schedules are advertised on the menus and billboards along with the day's specials. Because of their double responsibilities, women find forced changes in the hours of work even more stressful than men do, because the home work of cooking cannot be adjusted readily, particularly when there are young children.

Young men in their thirties are becoming involved in more than superficial ways with their children. Three men who were laid off have undertaken full responsibility for getting the children ready for school and preparing their lunches. We have observed men during interviews who managed the children very successfully and apparently without resentment, responding to the little crises of cuts and fights in an experienced manner. Working women all preferred to continue doing the shopping, an indication of greater managerial responsibility in food preparation, but men take charge of meals that they prepare for themselves and the children while their wives are working, and both share cleaning and laundry chores.

This redistribution of labor within the family does not involve extended family ties; it takes place within the nuclear family, where it is not ordinarily observed. All our respondents in the random sample of one hundred, except four unmarried youths, lived in their own home, and in only one case did a family in which the wife ordinarily worked have the assistance of the wife's mother living with her to help care for the children. Another woman's mother tried to take care of her daughter's children, but they both agreed it did not work out well, and a sitter was hired.

These changes are taking place so rapidly that data included in Hartman's summary from the late 1960s and 1970s no longer characterize the 
solutions being worked out in the 1980s. These findings seem to be corroborated by a study by Maret and Finley (1984) in two periods1974 and 1976 - showing consistent trends toward greater sharing of domestic tasks in that short span of years within the same households.

I had expected that there would be a significant difference between production workers and engineers in the amount of shared household responsibility. Although I have too few cases of the latter from which to generalize, I found that the job pressures on engineers to upgrade their knowledge by taking courses in the nearby colleges and in-job training meant that they were away from home much longer than the normal eight-hour working day. This left their wives even more in charge of the home, whether they worked or not.

The balanced reciprocity that occurs between spouses in the household may break down under stressful conditions. One man's first marriage could not survive the 101-day strike of 1969, when his wife went to work full-time and berated him for failing to support the family. Women who went on strike in the garment shop also describe the intolerance of husbands when they were involved in organizing meetings. They also seemed less willing to tolerate demands on their time and energy by their husbands when they became politicized by the union drive. Three women I interviewed separated from their husbands in the course of a four-month strike. A woman who took a "man's job" when the government required defense contractors to open up some of the segregated job opportunities in the plant made more money than her husband, who was working in the same shop she entered, because she received an "adder" (an amount added to regular wages when piecework was abolished). Although she denies that her marital breakup resulted from this threat to her husband's position, their twenty-year marriage, during which five children were born, did end shortly after.

What seems to happen is that personal transformations brought about by the structural changes occurring in the wider society raise questions about a given set of accommodations and precipitate new decisions. It is not simply an accumulation of grievances experienced over many years around the same set of expectations, but rather a break in the expectations, that precipitates a crisis of consciousness. The division between family and the industrial marketplace is a fragile eggshell, subject to shattering internal obligations that no longer conform to external demands. The sense of exploitation that women may have had was tempered by an awareness of the greater danger and hardship men experienced in jobs classified as male jobs. Older women resisted the 
breakdown in gender segregation in the plant because of this factor. With the implementation of the Equal Opportunity Act, when a woman was bumped from her job she was presented with both "male" and "female" jobs to be bumped to. Older women did not want the strenuous, dirty, and dangerous jobs, yet they could not turn down more than two such jobs without being permanently laid off. Equal opportunity, in this sense, plays into managerial control of the work force to an even greater degree than the sex-segregated jobs that gave women the option to refuse a whole category of those jobs.

The household as an arena of redistribution is indeed an important stage that conditions the wider social struggles. The quiet revolution taking place as men become familiar with domestic chores may become a paradigm for change in other arenas. Pronounced differences in the degree of responsibility men take on in the home is correlated with age, and the trend is toward increasing participation in household tasks measured in time and commitment. These changes were not legislated, as they were in Cuba (where the law makes it possible for a woman to bring her husband to court for failure to perform household chores), but rather changes in customs. Customary attitudes used to dictate full-time responsibility for domestic tasks whether a woman worked outside the home or not, but new rules and expectations are bringing about changes in personalities and roles related to gender. Vicky would not have considered it possible to neglect her husband's meals, even while Joan would not tolerate her husband's demands after she moved into a man's job at General Electric. But some younger women expect to find a hot meal already prepared when they come home from work.

\section{Redistribution and Government Mediation}

Government mediation through welfare provides an arena that, in Peattie and Rein's terms (1983:30ff.), serves to arbitrate and reconcile the claims of various groups and interests based on political and legal grounds. Peattie and Rein argue that because these claims for Aid to Families with Dependent Children (AFDC) or Medicaid do not stem from the beneficiaries' contribution to production, as in the case of wages, or contribution to reproduction, as a housewife in the family, they are outside the realm of "natural" claims. The ideological justification for these "artificial" claims comes either from input (as in Social Security, Medicare, and in a more remote sense, veterans' benefits) or from need (as in AFDC, food stamps, and Medicaid). 
Because government funds are derived from sectors of the population that may or may not benefit from such programs directly, the political interpretation of government redistribution does not follow from class relations in production. In Pittsfield, unionized production workers have a hierarchy of values related to government programs that categorize the programs funded by input as "victories of the labor movement" and those with a means test as "bureaucratic government spending." They try to avoid falling into this second category at all costs. I have known women who worked full-time even with small children at home and at minimum-wage rates lower than what they would receive from AFDC, and I have been told about elderly people eating cat food rather than ask for food stamps. Retired workers would prefer to negotiate their claims for higher pensions with their employer rather than with the state. "We built General Electric," say retired workers who organized a retirees' club related to the local, "and they owe us a pension that permits us to live in dignity." Dignity means without the help of children or welfare payments. Each year these retirees picket the plant, asking for donations from workers and making their claims on the corporation known.

The evolution of legislation concerning the human resources and welfare needs of the nation responded to structural changes in the population, to economic cycles, and to reevaluations of what the reciprocal rights and obligations of workers, citizens, and family members were. Only some of these emanated from production, where they were defined in terms of contribution to production. Others originated in the family and community and were related to problems of people who were not part of the work force. The recognition that-in addition to the deserving poor who were the target for charity and some public welfare at the turn of the century - the very nature of capitalist production required intervention to sustain those who suffered layoffs in industrial cycles and to provide for those who suffered from industrial accidents or disease came gradually. Added to these were the elderly who could no longer work, and youth entering the work force. The special concerns of women who were the sole support of children first came in the form of aid to widows in 1919, and only later were professional welfare services instituted for the divorced or never married mothers. The aged are a growing constituency who unite the problems of retired workers with those who never were in the work force.

Each increment of welfare involved a concomitant admission that the social institutions that involved the claimant were inadequate. At the same time, it required on the part of recipients a self-definition that 
made their needs explicit. The slow progress reflected both the resistance by the conventional institutions of work and family and community to admitting their inadequacy, and the clients' resistance to admitting their needs. The ideology of the free market pervades both donor classes and recipient classes in the United States and may be the reason the nation is lagging behind most other industrialized nations in social welfare (Wilensky 1975).

In order to overcome these obstacles to redistribution in the public arena, it is essential to develop a concept of a "social fund"-public revenues made available to social agencies working with the population that is to be served. First, to convince legislators, it is necessary to identify and enumerate the constituency that is in need. Second, the target population must be mobilized in their own defense. This requires a cognitive reorientation overcoming socialization practices that stress independence, individual solutions, and suffering in silence. Finally, it is necessary to reeducate people about the validity of these centralized funding agencies, which the public often identifies with graft and Tammany Hall practices. I shall discuss this process with regard to three groups whose needs are beginning to be addressed by public and private agencies: the youthful unemployed, female heads of families, and the retired in relation to their place in the changing composition of the population. The evolution of custom and law shows the interplay of ideology and behavioral norms in response to sectoral disparities in income and level of living that promote the redistribution of the social fund.

In none of these cases was the pooling and redistribution of funds an automatic response. Public recognition of a need was often a belated response to the increasing numbers of the cohort in the population. When retired workers began to live longer in the decade of the 1960s, they became a political force to reckon with; as the youthful unemployed increased in numbers, they found an advocacy group; and as divorced and unmarried female heads of households increased, programs related to their needs sprang up. What is needed with each group is a critical mass that will attract the attention of congressmen and senators. Tables 3.1 and 3.2 show trends in Pittsfield compared with national trends in the decade 1970-80.

Change in Pittsfield is in the same direction as national averages, toward an older population but at a greater rate. The percentage of people over age sixty-five is 14, up two points from 1970, while national averages are up 1.6 percent. While there are fewer in the youthful 
Table 3.1. Population Trends by Age-Group in Pittsfield, 1970-1980 (percent)

\begin{tabular}{lrrrrr}
\hline & \multicolumn{2}{c}{ United States } & & \multicolumn{2}{c}{ Pittsfield } \\
\cline { 2 - 3 } \cline { 5 - 6 } Age-Group & 1970 & 1980 & & 1970 & 1980 \\
\hline Under 5 & 8.4 & 7.4 & & 8.0 & 6.0 \\
$5-14$ & 20.0 & 15.0 & & 20.3 & 14.9 \\
$15-24$ & 17.5 & 18.4 & & 15.3 & 17.2 \\
$25-34$ & 12.2 & 17.0 & & 10.3 & 14.6 \\
$35-44$ & 11.4 & 11.6 & & 11.1 & 10.1 \\
$45-54$ & 11.5 & 9.6 & & 12.7 & 10.9 \\
$55-64$ & 9.1 & 9.6 & & 10.2 & 12.2 \\
$65+$ & 9.8 & 11.4 & & 12.0 & 14.0 \\
Total & 99.9 & 100.0 & & 99.9 & 99.9 \\
\hline
\end{tabular}

Source: "Unemployment Survey," Current Business, July 10, 1983, p. 3.

dependent category, ages up to twenty-four (38.1 percent, compared with 43.6 percent), national averages are slightly less-decreasing from 45.9 percent to 40.8 percent. The city has the same percentage in the earning years from age twenty-five to age sixty-five- -47.8 in Pittsfield, compared with 47.8 nationally.

The changes at the lower and upper ends of the population pyramid will have cumulative effects on the distribution of the social product. Predictably, there will be mare recipients of pensions and fewer donors to such funds as Social Security. Youth unemployment will further limit the contributions to the wage fund that is the major source of redistribution, particularly because corporate taxes have been increasingly cut. In

Table 3.2. Unemployment by Age-Group in Pittsfield, 1981-1982 (percent)

\begin{tabular}{lrr}
\hline \multicolumn{1}{c}{ Age-Group } & 1981 & 1982 \\
\hline All civilian & 7.6 & 9.7 \\
Men 20+ & 6.3 & 8.8 \\
Women 20+ & 6.8 & 8.3 \\
Both sexes 16-19 & 19.6 & 23.2 \\
White & 6.7 & 8.6 \\
Black & 14.2 & 17.3 \\
Married men & 6.0 & 7.4 \\
Women who head household & 10.4 & 11.7 \\
\hline
\end{tabular}

Source: "Unemployment Survey," Current Business, July 10, 1983, p. 3. 
the period 1970-82, female-headed families doubled, comprising 28 percent of families in the central cities and 17 percent in the suburbs. Among black families, those that are headed by females are the norm, with 52 percent falling into this category. These structural changes in household composition are correlated with increases in the number of women in the labor force and with increases in recipients of AFDC. While in 1982 the percentage of female-headed households in Pittsfield seems low when compared with national figures (11.7 percent in Table 3.2 ), it is rising. Women are fast becoming a critical political force by virtue of these changes that shift them from the status of dependent wife to independent wage-earner or dependent welfare recipient. The political change has been noted in the "gender gap" in voting behavior. ${ }^{8}$ The most marked change is in the proportions of the elderly-from a life expectancy age of forty-two in 1850, the life expectancy in the United States rose to age seventy-three in $1979 .{ }^{9}$

Demographic swings reach a critical mass when behavior is visibly affected by the numbers clustering in a given category. Although we do not have a calculus for determining when this happens, it is clear that such a mass has been reached in the political behavior of women and the elderly, who have become their own advocates for redistribution of the social product. Youth are less likely to make claims for themselves, but many groups rise in their defense, either out of concern for delinquent behavior of the untrained and unemployed or out of a commitment to salvaging a human resource. Action for government intervention is analyzed in relation to each of the age-groups below.

\section{Youth Programs}

Youth programs have moved from private, religious charities to public and private secularized agencies. At the turn of the century, the goals of the programs were in terms of moral improvement, but today the programs are cast in the idiom of sportsmanship and competition. The Young Men's Christian Association (YMCA), the Boys' Club, the Girls' Club, the Catholic Youth, and the Jewish Youth address the interests and problems of the young. The YMCA in Pittsfield was organized in 1888 , the Boys' Club around the turn of the century, and the Girls' Club

\footnotetext{
${ }^{8}$ Erie, Rein, and Wiget 1982 provide a particularly insightful analysis of the gap in gender political perception.

9Uhlenberg 1977 provides many insights into the changes in policies regarding age cohorts and the demographic shifts as each age comes to maturity.
} 
not until 1924. This reveals the greater concern with boys running wild if they did not have parental supervision. The YMCA's 3,500 members include many families drawn from middle-income groups. The 5,100 members of the Boys' Club include many children who have single parents, and they are generally considered to be from lower-middleclass income groups. All the clubs express a concern with developing a complete person, morally, physically, and mentally. Yet they differ not only in target populations but in aims. "The Boys' Club shoots with a shotgun at their clientele," the YMCA director told us. "We have a more rifle approach. We're after a concern, a task, and we aim for that group and we deal with it."

Movement from childhood into adulthood assumes movement from play to work roles. During the 1960s, recognition that prosperity did not automatically integrate all Americans in the rising economy led to some innovative programs designed to circumvent the welfare system while attending to the problems of the disadvantaged. Vista, the Job Corps, and community action programs recognized the disparities in education, job opportunity, and socialization processes. Initially the Job Corps was conceived for boys, because, according to Sundquist (1969:43), "it was typically young men rather than young women who were dropping out of school and the labor market." Later, the programs of the Comprehensive Employment and Training Act (CETA) involved the whole population, extending to the training and retraining of workers of both sexes and all ages. Job creation was included, along with job training in private industry. This meant that the service sector in other agencies was expanded by employing trainees in park work, hospitals, museums, and school lunch programs.

When CETA was transformed into the Job Training Participation Act in 1983, the immediate impact was a cut in the budget. In Pittsfield the budget went from $\$ 7.5$ million in 1978 to $\$ 1$ million in 1985 , and none of those separately funded efforts was secured for more than a few months. Job creation was removed, causing hardships in other agencies that had relied on the help provided by the trainees. The failure of any given participant in a program meant that the agency was given reduced allocations. In effect, this meant that all the financial risks of working with lower-class populations was shifted from public sources to these human-service agencies themselves. The emphasis on numbers of participants recruited and moved through the programs as the chief criterion in judging the programs further discouraged any creative activities.

Despite these setbacks, a dedicated staff of thirty to thirty-five, some 
of whom were recruited during the 1960s and 1970s, when expectations about overcoming inequality were high, try to respond to the many unmet needs that a staff of one hundred used to do. They try to assess what is needed in the labor market and adjust their training to that. They now have a sales and marketing program with North Adams College and a word-processing course at the Berkshire Community College, as well as many on-the-job training positions in about 200 different businesses for machinists, secretaries, dental assistants, plastics mold-makers, medical technicians, and nurses' aides, for instance. The programs tend to be aimed at an existing set of low-level entry occupations. This, combined with their dependent, step-by-step funding, discouraged any attempt to develop more creative careers. Employers benefit from the free employment services provided by the state, as well as from the wage subsidy during the training period and for a short time following fulltime employment. The further provision of tax credits to employers who employ trainees encourages such employment.

Head Start, one of the Great Society programs that has operated in Pittsfield for twenty years, began with classes for sixty-five students in 1965 and has increased to 242 classes in nine centers in Berkshire County. The program continues to take the holistic approach to health, nutrition, and social services-in addition to education, which marked its origins. The program enjoys strong support in the community, and its twentieth anniversary was noted with awards presented by the district's U.S. congressman. The program has served 3,900 children, whose progress was duly noted on the occasion of the anniversary.

\section{Female Heads of Families}

Women are taking the brunt of changing family norms, both in increasing poverty levels and as victims of abuse by husbands and estranged mates. Nine-tenths of families headed by a single adult in the United States are headed by females, and the numbers of female-headed families have doubled for blacks and increased by 75 percent for whites (Weiss 1984; HUD 1984). President Reagan took pride in his administration's cuts of $\$ 2$ billion in AFDC benefits and $\$ 2.3$ million in food stamps, but these cuts have removed the incentive for women receiving benefits to take on full-time (and often less secure) jobs because they would lose their benefits under the new regulations. According to a HUD report (1984:283), the "harsh rule that prohibits an AFDC recipient from disregarding any earnings after four months" makes AFDC 
recipients reluctant to "plunk into uncertain jobs," with the resulting problems of child care and complicated travel arrangements.

The Pittsfield office of the AFDC program has a staff of fifty-five, including thirty social workers, three administrators, and fourteen clerical workers. The caseload has dropped from an average of 1,789 clients a month in 1982 to 1,383 in 1985 . The drop can be attributed to the inability to do the outreach necessary for those who cannot work their way through the bureaucratic maze, not to a drop in need. The caseload has also declined despite rising need because of the way eligibility is figured since the Omnibus Reconciliation Act was passed.

The greatest need is that of those who cannot move through the bureaucratic maze, such as deinstitutionalized mental patients, alcoholics, and older people who reject welfare. Some cases that fall through the net are cared for by the Salvation Army and the Christian Center, which provide emergency rations and shelters. When welfare and food stamps are used up, or during the three weeks after application for welfare, there are seven emergency food pantries that serve about 375 families a month. The clients appearing in these emergency centers are increasingly families - not individuals, as was the case formerly.

My informant added, "Welfare is, for some, 'addictive." The subsidized rental, heating supplementaries, food stamps, and basic income of from $\$ 315$ for a family of two to $\$ 445$ for a family of four are extremely attractive in a fluctuating economy with layoffs continually threatening a wage-earner, and rising prices cutting into income. According to the welfare spokesperson, it is "very traumatic to leave Mother Welfare. It is a very warm and secure, though sometimes a demanding and demeaning institution." By minimizing the opportunity to combine income-earning opportunities with welfare, the Reagan cuts have eliminated exits from full dependency on welfare.

Rising numbers of people below the poverty line- 34.4 million in 1982 - indicate that more and more people are falling out of the safety net. There are estimates that 2 million are in need and not receiving help. The major initiative in the face of these declines is Reagan's "enterprise zones" for inner cities, which would remove taxes and regulatory "inhibitions"-minimum wage, union recognition, and other laws that were the fruit of fifty years of labor struggles to encourage employers to give the gift of a job to people (HUD 1984).

In response to specific needs of women and children, several groups have developed. The Women's Center in Pittsfield began as a volunteer group in 1975 and grew to a $\$ 175,000$ operation in 1982 . Its first activities 
were in intervention in times of crisis, usually precipitated by wife abuse. The center provided legal advocacy for divorce proceedings, a hiring hall, and job counseling. When a hotline for receiving calls was established, the number of calls increased from 295 in 1980 to 412 in 1981. The latest program, begun in 1983 and called "Displaced Homemakers," is funded by Bay State Skills with $\$ 171,000$ in 1983. Displaced Homemakers is directed at women whose lives are predicated on their roles as wives and mothers and who have suddenly lost claims to wage redistribution or Social Security benefits because of divorce or death of the spouse. The social worker who worked with these women compared them with veterans, who, she said, are also committed to carrying out "society's goals of protection of the nation and our home and our values," but whereas the veteran will receive educational benefits and be given preferred status in training for jobs, widows and displaced homemakers are the last to be hired and the first to be fired, because they lack seniority in the work force.

The dilemma women face in politicizing their claims is that they lose the rights that are defined in relation to dependent roles in the household when they seek autonomy as wage-earners or as claimants for public assistance. The failure of the Equal Rights Amendment to pass in state legislatures and become national law indicates the fear women have of losing their claims as dependents in a society which has thus far assumed that they will gain a share of the socially available surpluses by virtue of their status as wives and mothers. In this period of transition, any move to equalize their position in the labor market becomes a threat to that status. The legislation that came out of the New Deal "confirmed the dependency relationships of women and the deserving poor" (Erie, Rein, and Wiget 1982:2). By drawing in the minorities and the poor, the Great Society programs made the working majority feel threatened. Their sacrifices to advance their own mobility and that of their children seem negated by such help to the improvident.

Despite these contradictions, women have become the most vocal sector of the population in their attempts to redress the losses they experience as they move from the dependent status of wives and mothers, protected by a patriarchal family, to independent but subordinate members of the secondary work force. Along with the demands for rights in the workplace, they are looking for support among women to protest the increasing violence against women and children. In Pittsfield during the fifth annual "Take Back the Night" march in 1984, women spoke out for the right to walk without fear after dark without requiring a protec- 
tor. AWARE - the All Women's Advocacy, Relief, and Empowerment project in Pittsfield - works with the Battered Women's Task Force and the Women's Services Center to ensure legal support for women who have experienced assault.

\section{Retirees and the Aging Population}

The most significant legislation regarding redistribution to the older population is Social Security. The Social Security Act was the keystone for the construction of the welfare state when it was passed in 1935, and along with the Fair Labor Standards Act of 1938 it established the minimum wage and instituted the eight-hour day. In addition to regulating the labor market, it moved retired workers from the ranks of welfare recipients to pensioners and transformed disabled workers from beggars to independent status. Only later were wives and widows added. The system had grown from a limited insurance plan to a "gigantic tax system aimed at redistribution of current income from workers to retirees and other beneficiaries" (Mait 1978:35). The passage of the bill in 1935 was clearly related to the growing awareness of "the mounting human problems of dependent old age in an industrial urban economy," when "people could not go back to the security of the farm life, nor could they rely on the income from the recently laid off son. The loss of savings through bank failures and depreciated investments had reduced many self-reliant people to dependence on relief" (ibid., p. 43).

The increasing number currently covered by Social Security upsets the balance between the amounts contributed by employed workers and the benefits received by retirees. In 1940 there were 145.8 workers for each beneficiary, and by 1972 there were only 2.9 workers per beneficiary-an increase from 3 million recipients to 30 million. Since then the number of people receiving benefits directly and as beneficiaries has risen to 34 million, representing one-seventh of the total population of the United States and about one-third of the working population.

Declining employment rates attributable to deindustrialization and automation are in part responsible for the imbalance between workers and beneficiaries. In contrast to corporate managers, who have shown no concern with this problem at the local or national level, retirees from General Electric in Pittsfield have started a campaign for taxing robots to pay for Social Security. In June 1982, retired workers of the IUE Locals 254 and 255 went out on a picket line at the main gate of Pittsfield's GE plant. The messages on their signs should teach a historic lesson to plant 
managers, government representatives, and the public in general. One read: "Must We Beg FOR THE Good Things?" Another said: "A Decent Medical Plan Is Not a Luxury." But the statement that went beyond what we see in the media or business journals was Guy Pelegrinelli's sign: "Robots Should Pay Social Security."

The wording of the signs shows that workers have a more profound sense of the implications of technological change and its link with the redistributive system essential for maintaining the social system intact than do the hired economists of business or government. While management specialists in the burgeoning field of automation worry about the competitive market in gearing up plants for robots, workers in industry and those who are retired are concerned with the fundamental problems that threaten our society-first and foremost, unemployment. Without wages and income, who can consume the flow of products that robots are capable of producing? But no less important are the taxes needed to pay for the basic social services won over the years by organized laborpensions, Social Security, medical insurance, education for children, and retraining workers displaced by automation. Some method of redistributing the gains from production must be reinvented at the same time that robots are being substituted for human labor. The call of General Electric retirees for a tax on robots is an innovative solution to a problem that professional economists have not addressed.

Retirees have more immediate goals regarding their pension from General Electric. The pension fund has an annual interest return of $\$ 800$ million, only $\$ 400$ million of which is disbursed to living workers who are retired. Leo Rodgers, president of the retirees' club, stated the case for increasing pensions at a meeting of the IUE conference board during national negotiations. He pointed out that those who retired prior to 1970 averaged about $\$ 100$ a month from their GE pensions. This, added to $\$ 230$ a month from Social Security, did not cover normal expenditures in the year 1979. The pensions received by these retirees had been adjusted upward by 40 percent to account for inflation; yet in the same period, GE workers had received cost-of-living increases amounting to 115 percent. "The working people who produced goods for the world market," Rodgers pointed out, "enabled the existence and the flow of profits" of their employers. Retirees' past contributions to their industry should receive recognition in the form of increased pensions and an improved medical insurance plan.

In another area of redistribution, funds from state and private sources are pooled to provide for the needs of the elderly at home or in centers. 
The Berkshire Home Care service enables older people to remain in their own homes when they become unable to care for themselves completely by providing strategic services with a staff of paid and volunteer workers. Since 1974, when the service was begun, they have had a 90 percent increase in their casework, operating with a budget of $\$ 48,000$ initially and now with $\$ 2.5$ million. The homemaker volunteers help the elderly with light cooking and housework. They also provide bus service and health services, as well as nutritional centers, where advice on diet and instruction in food preparation are given.

Many of the general welfare aids in the county, such as assistance in paying energy and housing bills, are aimed directly or indirectly at senior citizens. More than 1,200 volunteers put in many hours working for the elderly throughout the county, in hospitals, as drivers providing rides for the elderly and the handicapped, and providing "meals-onwheels." Mental health counseling and a program called "Good Grief" help the elderly deal with death and dying. A hotline telephone service enables the sick to summon aid immediately. Legal services, occupational therapy, and free recreational trips enable the elderly to live active lives. An intergenerational child-care service promotes the extended ties that have been lost in so much of American life.

This extraordinary level of activity shows a remarkably successful fusion of community concerns typical of a small town, combined with the know-how and practiced administration of a bigger city. According to the director, the subtle balance of private and public funding and the mix of volunteer and professional help will go down the drain if federal funding is reduced, because stable input is necessary to build programs. Formerly, CETA workers mixed with the volunteers, "helping like one of the family." Reaganomics has destroyed this, and crippled the rest of the program as well. The specious call for turning such public activities back to private charities does not take into account that although well over 50 percent of these programs are already financed by funds from United Way and volunteer work, the core payments from regular federal government sources sustain the whole structure.

The complex network of service organizations with board members drawn from industry and labor is a complementary part of an anarchic mode of production in which workers and their families bear the brunt of shifts in the business cycle. These quasi-public agencies contrast with state welfare agencies, which categorize their clients as far removed from the hard-working, sports-loving, privatized family mode of living that characterizes other citizens. Even now, with many forced to go on 
welfare, some people would rather eat cat food than check out a grocery cart using food stamps. As these numbers increase, the onus for relief will shift from the recipients to the system for failing to provide employment. This time is fast approaching, as notable increases in emergency centers show. The nights of lodging provided by the Pittsfield Salvation Army totaled 6,750 from June 1984 to January 1985, and in December the local press (Berkshire Eagle, January 25, 1985) estimated that there were ten to twenty street people. The emergency meal centers provide about 375 families with food each month, and the state Department of Public Health found malnutrition affecting 2 to 4 percent of the children in the state (Berkshire Eagle, March 26, 1984).

\section{Conclusions}

Redistribution is a process of circulating resources and rewards within a social system in a way that reinforces a given structure of social relations. Claims for disbursements are based either on contributions to the common source of funding or on need. While this distinction seems clear-cut, the size of the distribution often bears little relationship to the contribution. Wages and salaries are never directly calibrated to the contribution of the individual even at the site of production, and far less in the area of sales, services, and transportation. Cultural variables modified and transformed by a power structure enter into the remuneration of everyone from the doorman to the highly skilled technician. A redistribution model enables us to perceive the political economy involved in all such transactions.

When we integrate the perspectives gained from an analysis of the redistribution in each domain, we can understand what structures the corporate hegemony. The redistribution of wage incomes that occurs in the home reinforces hegemonic power relations in the wider society when women remain married to wage-earners in the preferred sector of the labor force. Even when they are working at jobs with low incomes and no benefits, they can then rely on medical insurance as dependents, and support for children from the male wage-earner. But single heads of family recognize the exploitation that drives their wages below the costs of social reproduction, and it is they who go out on the picket lines protesting the low wages in the competitive firms or service jobs in which they work. Their double disadvantage as women and as workers in segregated, low-paying jobs is compounded by women's disadvantaged position as single heads of families with no backup help at home. 
Thus women are the principal clients of state agencies that have intervened to modify discrimination on the job or that disburse income maintenance funds. The rising number of women in the labor force-up to 37 million in 1979, compared with 20 million in 1960-is matched by rising levels of welfare costs, which have gone from $\$ 25$ billion to $\$ 264$ billion in 1979 (Erie, Rein, and Wiget 1982:1). Reversals cutting $\$ 35.2$ billion from social outlays since 1982 have been especially traumatic for women and children. These major upheavals threaten the basis for security, and even the survival, of this population. As yet, the "gender gap" that surfaced in the congressional elections of 1982 has not extended to the presidential elections, nor has the surface discontent been translated into a deeper consciousness of what the issues are in political economic terms. Welfare dependency may have undermined some of the political responses to changes in the 1970s, but the removal of most subsidies may counteract such trends.

As we compare the claims stemming from the arenas of production, reproduction, and governance, we can see the ideological bases for validation of shares in production. Sometimes the claims from two arenas are convergent, as when retirees seek to reinforce the process of redistribution with a tax on robots, thus limiting the firm's tendency to replace wage-workers with machines, and at the same time replacing taxes lost on wages; or when displaced homemakers demand status akin to the veterans who have served their country, in seeking reentry into the labor force in a privileged position. These kinds of convergences will strengthen the political basis for realizing their claims. More often, the claims from different arenas are taken as contradictory, as when widows of Social Security recipients try to continue work and lose most of those benefits. Wage-workers in the primary sector tend to view all the welfare interests as a threat to their take-home pay, instead of seeing the advantage they may have when welfare disbursements overcome the desperation of job-seekers who might otherwise drive down the wage rate. According to Piven and Cloward (1982), Great Society programs strengthen the political position of the work force as well as of those who can stay out of it because of subsidies, and the current attack on welfare is in recognition of its effect on the accumulation of capital.

The evolution of legislation in the 1930s set a floor for impoverishment in the United States. That floor became a staging area for the Great Society programs that brought about a redistribution of wealth in the 1960s. A study by the U.S. Bureau of the Census (New York Times, April 17, 1985) demonstrated that these programs, including Social Security and AFDC, reached 45 percent of all households, or 39.1 
million of the nation's 83.6 million households. Of this total, 37 percent received entitlements that did not require a needs assessment, and 19 percent received aid from programs geared to the needy. The 1985 budget submitted to Congress made deep slashes in these programs, with cuts of $\$ 18.7$ billion over the next three years to Medicare, $\$ 5$ billion to Medicaid, and reductions in rental assistance, public housing, congregate meals, and meals-on-wheels, as well as low-income energy assistance and legal services. The total amount cut from all domestic spending for the fiscal year 1986 was $\$ 30.4$ billion, an amount that just about equaled the sum that was added to the budget for military spending. The guns-or-butter choice, wrote Seymour Melman (New York Times, April 22, 1985), can no longer be ignored: either we continue escalating the arms race and destroy programs that would ensure the productive potential of our nation or we "couple a joint process of agreed arms reduction with conversion from a military to a civilian economy."

As the wage basis for claims on the system is narrowed through automation and robotization, the need to strengthen claims on other grounds becomes increasingly important. Peattie and Rein (1983) highlight this in their equation of earning "not as an isolated economic factor but as institutionally determined as claims on consumption arising out of kinship relations or through the welfare system." The diminishing share of wages in the gross national product and the failure to tax rising corporate profits by the Reagan administration threaten the basis for social welfare legislation. We need to restore the basis for claiming a larger share of production by underwriting the legitimate claims of families and communities with continuous funding of programs with an institutional basis that takes them out of a political feuding arena.

\section{REFERENCES}

Bibb, Robert, and William H. Form. 1977. "The Effects of Industrial, Occupational, and Sex Stratification on Wages in Blue-Collar Markets." Social Forces 55(4):974996.

Boltwood, E. 1916. The History of Pittsfield, Massachusetts from the Year 1876 to the Year 1916. Pittsfield, Mass.

Brenner, M. Harvey. 1973. Mental Illness and the Economy. Cambridge, Mass.

Chinoy, Eli. 1955. Automobile Workers and the American Dream. Garden City, N.Y.

Edelman, Murray, and R. W. Fleming, eds. 1965. The Politics of Wage Price Decisions: A Four Country Analysis. Urbana, Ill. 
Erie, Steven P., Martin Rein, and Barbara Wiget. 1982. "Women and the Reagan Revolution: Thermidor for the Social Welfare Economy." Paper presented at 1982 Annual Meeting of the Western Political Science Association, San Diego, California.

Freeman, Roger A. 1981. A Preview and Summary of the Wayward Welfare State. Stanford, Calif.

Galbraith, John Kenneth, and Paul W. McCracken. 1983. Reagonomics: Meaning, Means, and Ends. New York.

Gluckman, Max. 1968. "The Utility of the Equilibrium Model in the Study of Social Change." American Anthropologist 70(2):219-237.

Goldberg, Joseph, et al. 1975. Collective Bargaining and Productivity. Champaign, Ill.

Gordon, D., M. Reich, and R. C. Edwards. 1982. Segmented Work, Divided Workers: The Historical Transformation of Labor in the United States. Cambridge, Eng.

Greenwood, R. G. 1974. Managerial Decentralization. Lexington, Mass.

Hartman, Heidi. 1981. "The Family as Locus of Gender, Class, and Political Struggle: The Example of Housework.” Signs 6(3):366-394.

Heldman, Dan C., James T. Bennett, and Manuel H. Johnson. 1981. Reregulating Labor Relations. Dallas.

Magdoff, Harry, and Paul Sweezy. 1981. The Deepening Crisis of United States Capitalism. New York.

Mait, Stephen H. 1978. "Social Security: A Program to Prevent Poverty." In Herman Berliner, ed., Programs to Prevent or Alleviate Poverty (Hofstra University Yearbook of Business Series) 12(2):32-113.

Maret, Elizabeth, and Barbara Finlay. 1984. "The Distribution of Household Labor among Women in Dual-Earner Families." Journal of Marriage and the Family 46:357-364.

Marx, Karl. 1973. The Grundrisse. Middlesex, Eng.

Matles, James J., and James Higgins. 1974. Them and Us: Struggles of a Rank-andFile Union. Boston.

Montgomery, David. 1979. Workers' Control in America: Studies in the History of Work, Technology, and Labor Struggles. New York.

Nash, June. 1983. "Segmentation of the Work Process in the International Division of Labor." In Steve Sanderson, ed., The Americas in the New International Division of Labor, pp. 253-272. New York.

- 1984. "Impact of the Restructuring of the World Capitalist System on the New England Industrial Community." In C. Bergquist, ed., Labor Systems and Labor Movements in the World Capitalist Economy, pp. 243-266. Los Angeles. Oakley, A. 1974. The Sociology of Housework. New York.

Passer, Harold C. 1953. The Electrical Manufacturers, 1875-1900: A Study in Competition, Entrepreneurship, Technical Change, and Economic Growth. Cambridge, Mass.

Peattie, Lisa, and M. Rein. 1983. Women's Claims. Cambridge, Mass.

Piven, F. Fox, and Richard A. Cloward. 1982. The New Class War. New York. 
Polanyi, Karl, Conrad M. Arensberg, and Harry W. Pearson. 1957. Trade and Market in the Early Empires. New York.

Ricardo, David. 1930 (1821). "Principles of Political Economy and Taxation." Reprinted in Joseph Freeman, Joshua Kunitz, and Louis Lozowick, eds., Voices of the Industrial Revolution. New York.

Smith, E. A. 1876. The History of Pittsfield, Berkshire County, Mass., from the Year 1800 to the Year 1876. Springfield, Mass.

Sundquist, James L., ed. 1969. On Fighting Poverty: Perspectives from Experience. New York.

Sweet, Morris L. 1981. Industrial Location Policy for Economic Revitalization. New York.

Uhlenberg, P. 1977. "Changing Structure of the Older Population of the U.S.A. during the Twentieth Century." Gerontologist 17:197-202 (June).

U.S. Department of Housing and Urban Development (HUD). 1984. Community Planning and Development: Urban Conditions and Trends. The President's National Urban Policy Report. Washington, D.C.

U.S. Department of Labor, Bureau of Labor Statistics. 1982a. Labor Force Statistics Derived from the Current Population Survey: A Databook, Bulletin 2096. Washington, D.C.

- 1982b. Unemployment and Its Effect on Family Income. Bulletin 2148. Washington, D.C.

Walton, Clarence C., and Frederich W. Cleveland. 1964. Corporations on Trial: The Electric Cases. Belmont, Calif.

Weiss, Robert S. 1984. "The Impact of Marital Dissolution on Income and Consumption in Single Parent Households." Journal of Marriage and the Family 46:115-27.

Wilensky, Harold. 1975. The Welfare State and Equality: Structural and Ideological Roots of Public Expenditures. Berkeley and Los Angeles.

Willison, G. E. 1957. The History of Pittsfield, Mass., 1916-1955. Pittsfield, Mass.

Zaretsky, E. 1976. "Capitalism, the Family, and Personal Life." Socialist Revolution, nos. 13-14. 